\title{
Practices of brand extensions and how consumers respond to FMCG giants' greening attempts
}

\author{
Andreas Hesse $^{1}\left[\right.$ D $\cdot$ Karolin Bündgen ${ }^{1} \cdot$ Saskia Claren $^{1} \cdot$ Sarah Frank $^{1}$
}

Revised: 14 January 2022 / Accepted: 19 January 2022 / Published online: 10 February 2022

(c) The Author(s), under exclusive licence to Springer Nature Limited 2022

\begin{abstract}
We aim for a deeper understanding of how the theory of green brand extension is effectively used in brand management practice. Therefore, we conducted three consecutive studies to unfold corporate activities as well as consumer perceptions. (1) Employing a qualitative content analysis, we explore and explicate characteristics of 37 green brand extensions. (2) We discuss green brand extensions in four focus groups and categorize facets of consumer skepticism. (3) To deepen and triangulate the findings, we conduct 50 interviews with consumers with a wide range of environmental involvement. Our theoretical sampling offers rich insights into perspectives of consumers, however, limited to personal reflections on a subset of brands in the German FMCG market. First, we unveil three characteristics of green brand extensions, based on their benefits and beneficiaries. Moreover, we emphasize that in contrast to the original brand extension theory, the main image transfer is intended to focus on reverse greening effects. Second, we note that consumer responses reflect various categories of skepticism around FMCG giants as originators of such extensions as well as their underlying intentions. In addition, we interpret different effects of ecolabeling linked to its sender. Third, we empirically demonstrate that consumers with a higher environmental involvement can be expected to scrutinize green brand extensions more critically. Moreover, we describe consumer perceptions and evaluations linked to brand loyalty and brand knowledge.
\end{abstract}

Keywords Brand extension theory · Green brand extensions · Fast-moving consumer goods (FMCG) · Qualitative research $\cdot$ Brand loyalty $\cdot$ Ecolabeling

\section{Introduction}

"With a good product based on ecological concerns, the potential for a marketer seems to be impressive." (Kassarjian 1971, p. 65)

The association of products and brands with environmentalism and social issues is a long-standing trend in marketing

Andreas Hesse

ahesse@hs-koblenz.de

Karolin Bündgen

karolin-buendgen@t-online.de

Saskia Claren

saskia.claren@hotmail.de

Sarah Frank

sfrank2@hs-koblenz.de

1 Faculty of Business Sciences, Koblenz - University of Applied Sciences, Konrad-Zuse-Str. 1, 56075 Koblenz, Germany and brand management (Anderson and Cunningham 1972; Kassarjian 1971). In 2019, protest events like "Fridays for Future" testified to a greater awareness of the public debate about climate change (Iglesisas et al. 2019). Societies have since experienced disruptive changes in their consumption behavior and their relationship to brands because of the Coronavirus pandemic (Campbell et al. 2020). Corresponding to both contextual trends, we are seeing a rise in the number of companies engaging in corporate social responsibility (CSR) (Caroll 1979), green marketing (Peattie and Crane 2005; Chen 2010) and societal marketing (Drumwright and Murphy 2001). In practice, activities like green advertising, the use of ecolabels as well as a plethora of new green products illustrate the swarm of activities around the eco-theme (Lin and Chang 2012). In various cases, companies have been accused of exploiting the greening approach with the sole motive of increasing profit (Rahman et al. 2015). Consequently, the imprudent and tactical usage of green marketing activities has led to consumer skepticism and assumptions 
of greenwashing (Alves 2009; Gordon 2002; Nyilasy et al. 2013; Olsen et al. 2014).

The introduction of eco-friendly new or modified products is emerging as a popular strategy among the wide variety of green marketing activities (Bonini and Oppenheim 2008; Olsen et al. 2014; Victory et al. 2021). Companies in the fast-moving consumer goods (FMCG) industry in particular are taking advantage of this phenomenon (Durif et al. 2010; Olsen et al. 2014). Brand extension strategy has to date been a more cost-effective and less risky alternative for modifying a product line or entering a new market, since the business capitalizes on its well-established brand name (Aaker and Keller 1990; Miniard et al. 2020; Pontes and Pontes 2021; Su et al. 2021; Tauber 1988). Meanwhile, the generic terminology has been broadened to green brand extensions implemented as green line extensions or green category extensions (Chatterjee 2009; Olsen et al. 2014). The former type describes the development of a green product modification within the same product category, e.g., through the usage of eco-friendly ingredients. The latter method involves using the parent brand to enter a different product category with an eco-friendly offer (Chatterjee 2009). In this article, we focus on the examination of FMCGs-encompassing consumer packaged goods like household cleaning products, cosmetics, toiletries, and groceries-launched as green brand extensions of established brands in Germany. In this context, consumers' reluctance toward green products (i.e., because of costs, inferior taste, or quality) is intended to be reduced by associating green products with established brands. On the other hand, "bringing to mind the non-green version" (Majid and Russell 2014, p. 994) may limit the brand's ability to position itself as green and eco-friendly. Accordingly, this may result in a negative image shift and greenwashing attempt.

It is beyond doubt that corporations widely apply brand extension strategy; however, both success and failure can still be observed (Victory et al. 2021). An extension can be categorized as successful if it has "not been pulled from retail shelves" (Grasby et al. 2021, p. 9). The German drug store retailer $\mathrm{dm}$ is perceived to have successfully established green brand extensions of their store brands (e.g., Alana and Alverde), mainly by emphasizing the brands' CSR approach and expanding green communication strategies (Waßmann 2013). Within this context, various brands can be observed launching green marketing strategies in line with their business missions on the corporate level, e.g., Unilever has developed a comprehensive "Five Levers for Change" program including behavioral rules for consumers (Romani et al. 2016). Unilever's ice cream brand Ben \& Jerry's is a prime example of successful ethical brand positioning (Hutchinson et al. 2013). Their commitment to "a positive, life-giving environmental impact that restores degraded natural environments and enables increased diversity and abundance of ecosystems" (Ben \& Jerry 2020a, n.p.) provides substance for the introduction of corresponding vegan non-dairy brand extensions (Ben \& Jerry 2020b). Internationally, Suki (2013) reported successful use of ecolabeling of "energy-star" by Hewlett Packard in Malaysia.

Brand extension theory has not yet provided adequate answers to questions of whether green brand extensions differ from their non-green predecessors in terms of characteristics and consumer evaluations (Olsen et al. 2014). Furthermore, there is a continued lack of understanding of the implications that green brand extensions have for their parent brands. Based on the above, we address the following consecutive research questions: (a) How do FMCG brands in the German market make use of green brand extensions? (b) When companies engage in green brand extensions, how do consumers perceive those extensions? (c) How do consumers express whether and how green brand extensions influence the parent brand image? In addition, we try to link consumer self-reports of perceptions and evaluations of green brand extensions to theoretical concepts of environmental involvement, brand loyalty and brand knowledge. Stemming from our primary data, we furthermore identify ecolabeling as one of the more important characteristics of how brands add value to green brand extensions.

Our research design covers three sections: In an explanatory approach, we deductively assess whether and to what extent the theory of brand extensions following Tauber's (1988) typology of levers is applicable to green brand extensions in the German FMCG market. Accordingly, Study 1 enables us to explicate corporate practices and re-check the strategic approach of brand extension. Empirically, we next use that material in discussions with consumers in four focus groups in Study 2. We choose a theoretical sampling representing well-educated participants from diverse demographic and income classes. In Study 3, we collect additional data from 50 interviewees, theoretically sampled with a wider range of environmental involvement. This study complements Study 2 and concentrates on the analysis of consumers' involvement in environmental issues as well as unveiling further characteristics of consumer perceptions. The thoughts, beliefs and expressions of the interviewees enable us to contrast nuances of consumer acceptance and consumer skepticism.

Our findings demonstrate how companies cope with green marketing strategies by introducing green brand extensions-in the example of the German FMCG market. We develop three categories of benefits of green brand extensions, and we emphasize that compared to the original theory, the image transfer from the brand extension backward to the parent brand is the major intention. Moreover, concentrating on the consumer perspective, we explore dark sides of consumer perceptions of green brand extensions manifested in different categories of skepticism. We reveal 
that the size of corporations and their environmental reputation are factors that limit the scope of a green brand. Moreover, we indicate that consumers doubt the intended positive reciprocal effect on parent brands. Based on 50 interviews, we underpin the role of environmental involvement. We note that consumers with a higher environmental involvement can be expected to scrutinize green brand extensions more critically.

\section{Theoretical background}

Since the 1980s, brand extensions have been a popular marketing strategy to introduce new products to a market without establishing a new brand (Aaker and Keller 1990; Nyilasy et al. 2013; Park et al. 1986; Tauber 1981). Although the theory was developed many years prior to our study, it is applicable to current brand research. In the following sections, we refer to the corresponding research that explains the antecedents or elements of consumer responses to brand extensions. However, while prior research about brand knowledge and brand loyalty does not exclusively concentrate on (green) brand extensions, this body of knowledge is helpful in deepening the interpretation of how consumers respond to green brand extensions. Finally, we introduce the construct of environmental involvement, which will be applied in our empirical investigation.

\section{Brand extension theory}

The main rationale employed by firms using established brand names to facilitate new product introduction is to minimize the costs and risks (Aaker and Keller 1990). In contrast to completely new product and brand launches as well as to concepts such as second brand or flanker brand, all brand extensions are based on the continued use of the parent brand (Olsen et al. 2014; Tauber 1981). Line extensions facilitate entry into new segments within the product category, while so-called category extensions use the current brand name to enter a new product category (Tauber 1988). The term brand extension is used as an umbrella term for both extension strategies throughout our article (Chatterjee 2009; Tauber 1988).

Line extensions deepen the product line by introducing an additional element, for example, new flavors, product or packaging sizes, colors, or ingredients (Chen et al. 2017; Kotler and Keller 2012). Thus, the aim of line extensions is to adapt the existing product to specific consumer needs or the needs of different consumer groups and therefore to promise the highest possible market coverage (Tauber 1981). Category extensions, on the other hand, leverage the entrance of new categories, which will involve a bigger step by introducing a whole new item compared to line extensions and will pay off in achieving market expansion with new products into new segments (Grasby et al. 2021).

Aaker and Keller (1990) provided a framework for consumers' evaluation of brand extensions that is based on the quality of the parent brand, the fit between the parent brand and the extension, and the similarity of the extension to the parent brand. The perceived parent-extension fit is defined as the consumer's logical acceptance as well as the expectation regarding the introduced extension (Tauber 1988). A higher perceived fit or similarity between parent and extension can predict success of the extension (Johnson et al. 2019; Liang and $\mathrm{Fu}$ 2021; Miniard et al. 2020). In addition, transferability and complementarity can facilitate a successful introduction of the extension (Bottomley and Holden 2001). Hence, the likelihood of success is higher when parent brand and extension are more similar; thus, there is a preference for line extensions instead of category extensions (Jain et al. 2020). In the case of co-branded brand extensions (e.g., Nike Apple Watch), brand extension authenticity-defined as consistency in style and aesthetics-complements the factors with an influence on the perceived fit (Sattayawaksakul et al. 2019)

Alongside introducing the concept of brand extension, Tauber (1988) conducted a systematic study regarding the types of leverage in brand extensions and stated that each observed brand extension is classified into one of seven types (see Table 1), although some may cover several types. The transfer thereby mainly builds on the characteristics of the point of origin (the parent brand).

In addition to the dimensions presented by Tauber (1988), which explain the transfer from the parent brand to the brand extension, effects which act from the extension back to the parent brand, i.e., reciprocal effects, are intended and should be considered. On the one hand, a revitalization or renewal of interest can represent a positive impact resulting from extending a brand; on the other hand, "an ill-conceived brand extension may seriously damage the original product and preclude the establishment of another brand with its unique associations and growth potential" (Aaker 1990, p. 47).

Studies outside the green domain have reported how brand loyalty facilitates the success of brand extensions and

Table 1 Dimensions of brand extensions' fit (Tauber 1988, p. 29)
(1) Same product in a different form
(2) Distinctive taste/ingredient or component
(3) Companion products
(4) Same customer franchise
(5) Benefit, attribute or feature owned
(6) Expertise
(7) Designer image/status 
that brand knowledge can dominate the image transfer in both directions (Schmidt et al. 2017). Furthermore, brand reputation (Johnson et al. 2019), information transparency (Bhaduri and Copeland 2021), brand image (Chuah et al. 2020) and trust (Chen et al. 2020) may indicate consumer responses to brand extensions.

\section{Green marketing and green brand extensions}

In recent years, green marketing, as the environmental pillar of CSR activities incorporating marketing objectives, has been one of the emerging notions in the field of marketing (Chen 2010; Chen et al. 2020). Green marketing is defined as a holistic strategy that manages the relationship between the company along with its stakeholders and the responsibility of guarding human and environmental dimensions while pursuing marketing objectives (Lerro et al. 2018; Peattie and Crane 2005; Polonsky 1994; Polonsky and Rosenberger III 2001). Although the current hype gives the impression that green marketing is in its fledgling stages, the idea of incorporating ecology into a marketing strategy was introduced as early as the 1970s, and the literature on green marketing has grown significantly in the past few decades (Anderson and Cunningham 1972; Kassarjian 1971; Nyilasy et al. 2013). Green marketing research has provided empirical evidence of the influence of green marketing campaigns, e.g., in the form of green advertising, on consumers' perception of brands (Chen et al. 2020; Grimmer and Woolley 2014). However, such effects can be positive or negative in the sense that consumers question the corporation's motives for such strategies (Groza et al. 2011).

Introducing green brand extensions of an existing brand is understood as a green marketing activity. Following Olsen et al. (2014), such green products refer to products that offer environmentally sustainable features. In detail, Durif et al. (2010) define a green product that does not necessarily have to be an extension as a product "whose design and/or attributes and/or production and/or strategy uses recycling (renewable/toxic-free/biodegradable) resources and which improves environmental impact or reduces environmental toxic damage throughout its entire life cycle" (p. 31). To develop green products, product marketers must consider materials, sources, carbon footprints as well as packaging in terms of being biodegradable and disposable (Kotler 2011).

Green brand extensions may achieve two objectives at once: First, they fulfill the requirements of environmentally aware consumers; second, similarly to non-green brand extensions, the new product can have a "synergistic ruboff" (Tauber 1981, p. 41) on the parent brand. Chatterjee (2009) provided empirical evidence for a positive reciprocal effect of green category extensions due to environmental associations. The equity of the parent brand may thereby be enhanced by this positive green image and halo effect
(Olsen et al. 2014). In contrast, various studies emphasize the risks of the reciprocal impacts of brand extensions (Hill and Lee 2015; Vahdat et al. 2020). However, today, marketers try to utilize the opportunities for reciprocity by launching green brand extensions for the purpose of greening the parent brand (Olsen et al. 2014). This green marketing strategy intends to offer new business opportunities in terms of extending product ranges and in particular, a differentiation from similar but non-green alternatives. Specifically, green line extensions, i.e., a dairy yogurt brand introduces a dairy-free variant (Grasby et al. 2021), typically substitute for or complement the existing product by adding a green alternative. Prior research thereby included the competitive landscape, i.e., whether the extension category incumbents are already established or not (Pontes and Pontes 2021). In addition, the influence of the environmental reputation of the parent brand on its green extendibility is to be considered in combination with the parental fit of the extension (Johnson et al. 2019).

\section{Ecolabeling}

Consumers use a variety of methods to reduce risks such as the selection of well-known brands, brand loyalty, endorsement of others, or certification and labeling as a cue (Aaker and Keller 1992; Grasby et al. 2021; Liang and Fu 2021; Suki 2013). In the case of green products, ecolabels are reported as having an important influence on consumers' perception and evaluations of products (Alamsyah et al. 2020; Canavari and Coderoni 2019). Accordingly, brands increasingly provide more detailed environmental information about their products and services (Taufique et al. 2017); however, ecolabeling needs to be specific about the ingredients and carbon footprint (Kotler 2011). The surge in ecolabels goes hand in hand with the surge in green brand extensions and new green products. Correspondingly, consumers are confused by the number of different labels used on product packaging (Schmidt et al. 2017; Sharma and Kushwaha 2019). The purpose of linking a brand to an ecolabel is to embed sustainability into the brand knowledge, hence providing value for consumers (Schmidt et al. 2017; Suki 2013). Ecolabels are often visualized with green color codes and described with terms like "eco," "bio," "organic," "fair trade" and "vegan." However, such ecolabeling schemes are intended to work as heuristics to support decision making and provide transparency, differentiation, and reduce information search costs (Canavari and Coderoni 2019; Hutchinson et al. 2013; Sharma and Kushwaha 2019). Promotion of ecolabels can be observed in various forms: proprietary developments of established brands, government certificates, and neutral non-governmental labels populate product packaging. Whether consumers trust ecolabels or not can be linked to the promoter of the label: Taufique 
et al. (2017) summarize that consumers are less likely to trust labels promoted by for-profit organizations than by independent and neutral third parties. Consumers formulate various inferences based on labelling, which can be biased by contextual factors as well as brand information (Cho and Baskin 2018). Correspondingly, Schmidt et al. (2017) noted the need for an "ecolabel-brand fit" (p. 7).

\section{Brand loyalty}

Brand loyalty is a concept that explains consumers' tendency to rebuy and re-patronize a preferred brand consistently after making positive brand experiences and building trust and attachment (Liang and Fu 2021; Panda et al. 2019; Vahdat et al. 2020). Successful brands have established strong relationships with consumers, thus allowing for increased brand loyalty and, consequently, promising a more positive perception of potential brand extensions (Ma and Kaplanidou 2021). It is expected that an existing loyalty encourages cross-purchasing within and beyond categories (Grasby et al. 2021). Correspondingly, research on corporate service brands has provided empirical evidence for an indirect impact of customer-perceived ethicality on customer loyalty (Markovic et al. 2015). In contrast, if loyalty to the parent brand category is low, "consumers may not transfer their attitudes, affect, or intentions toward the parent to the extension" (Liang and Fu 2021, p. 18). This may explain the empirical evidence provided by Chen et al. (2020), who noted that brands' greenwashing activities have a negative effect on consumers' green brand loyalty. However, research on the effects of brand loyalty on consumer acceptance of brand extensions is scarce (Grasby et al. 2021; Liang and Fu 2021).

\section{Consumer perceptions of green brand extensions}

While prior research is focused on consumer perception of brand extensions, it is unknown whether such consumer perceptions apply to green brand extensions in particular. Increasing consumer consciousness about health and environmentalism can be classified as one of the triggers of the green brand extension surge; however, it may also lead to skepticism and distrust (Bhaduri and Copeland 2021; Chatterjee 2009; Iglesias et al. 2018). Customer trust (e.g., in the capabilities, integrity, and benevolence of parent brands) is a strong prerequisite for positive evaluations of green brand extensions (Chen 2010). Durif et al. (2010) categorize the element of doubt and distrust in consumers' minds about the greenness of products as a greenwashing phenomenon. Greenwashing is defined as a form of disinformation from organizations seeking to shape their public image as environmentally friendly (Laufer 2003). Prior research has noted that consumers' perception of greenwashing negatively affects the perception of brands (Schmuck et al. 2018) and negatively influences consumers' green purchase behavior and green brand loyalty (Chen et al. 2020). In that sense, companies launching green products for the sake of reciprocally greening their parent brand may be accused of greenwashing their parent brand. Hence, the existence of consumer skepticism as well as the shift in consumers' demands and expectations have limited the likelihood of success for green brand extensions. More than ever before, to be successful, such products need to offer a desirable essential benefit for the consumer, such as cost savings or improved product performance (Nyilasy et al. 2013). If the latter is the case, consumers show a high willingness to pay for goods to preserve the environment, especially "when the giving is public and can influence one's reputation" (Griskevicius et al. 2010, p. 393). Similar consumer responses have been seen in the context of CSR initiatives. Accordingly, consumers are expected to be more positive toward those CSR initiatives that are integrated into the core positioning of the brand (Du et al. 2007) and that have a good fit with the brand.

Limited to the US fashion industry and a sample consisting of Generation Y consumers, the study by Hill and Lee (2015) empirically demonstrated that consumer knowledge about sustainability and consumers' existing evaluations of a firm's sense of environmental responsibility have an influence on their perception of green brand extensions as well as on potential reciprocal effects. Consumers with deeper environmental knowledge thus tend toward more pro-environmental consumption behavior and more positive perceptions (Taufique et al. 2017). Consumer perceptions of green messages, brands, or products are influenced by transparency and the information that is provided about the greenness, e.g., via ecolabeling. While consumers increasingly rely on ecolabels provided by brands, governments or NGOs, much of the information is perceived as misleading, and consumers' confusion increases, particularly when the sources are not credible (Taufique et al. 2017).

\section{Environmental involvement}

Different consumers respond differently to green cues and other green marketing stimuli. As a predisposing variable, environmental involvement can have an influence on the cognitive process of consumer perceptions of green brand extensions (Kroeber-Riel et al. 2009). Matthes et al. (2014) demonstrated the level of environmental involvement of consumers as a key variable regarding consumer responses to green advertising. Based on the Elaboration-Likelihood Model, consumers' perceptions of objects are categorized as more or less personally relevant (Petty and Cacioppo 1986). Environmental involvement or green involvement refers to the degree to which a person perceives an attitude object, in this case in the context of environmental brand-relevant 
issues such as green products, packaging, ecolabels or advertising, as personally relevant (Matthes et al. 2014; Petty and Cacioppo 1986). Hence, a higher environmental involvement of a consumer may predict a critical appraisal and substantive discussion of arguments regarding green brand extensions (Chuah et al. 2020; Grimmer and Woolley 2014; Matthes et al. 2014; Trump and Newman 2017). Particularly, if consumers believe that "a parent brand company is taking advantage of the ecological cause and trying to capitalize on it to promote its own branded products they will respond ... with higher levels of skepticism" (Romani et al. 2016, p. 255). Moreover, highly involved consumers may pay less attention to specific information, i.e., ecolabeling (Cho and Baskin 2018). However, Schmuck et al. (2018) demonstrate that even consumers with a higher "expertise in environmental matters are not entirely resistant to greenwashing" ( $p$. 128). The authors summarize that consumers with a higher involvement more readily recognize attempts to mislead in green advertising. Nevertheless, Panda et al. (2019) indicate that a higher sustainability awareness predicts higher levels of green purchase behavior and green brand loyalty. Conversely, lower levels of skepticism are predicted to be present in consumers who recognize the benefits of green marketing activities for the environment (Romani et al. 2016). Moreover, Lin and Chang (2012) examined a different facet of environmental consciousness and demonstrated that consumer usage behavior with regard to environmentally friendly or green products varies depending on the individual's environmental awareness.

While Aagerup and Nilsson (2016) report "an emerging understanding that other factors beyond internal environmental attitudes, values and norms may influence whether consumers choose to buy green products and services" (p. 274), we collected data referring to the construct of environmental involvement to better understand and explain consumer responses to green brand extensions. Accordingly, our study relies on environmental involvement conceptualized as (1) environmental concern, (2) attitudes toward green products, and (3) green purchase behavior (Matthes et al. 2014).

\section{Research objectives and methodology}

Globally, the FMCG industry is characterized as one of the most competitive and dynamic sectors (Niedermeier et al. 2021). Regarding the green movement, scholars have noted that for instance, almost all house cleaning product manufacturers have developed green product alternatives. Yet, at the same time, the FMCG industry and its supply chain represent pollution, solid waste, in particular plastic packaging, and the over-consumption of modern societies (Athavaley 2009; Niedermeier et al. 2021). Since European markets have a longer history of environmental concern (Olsen et al. 2014) and, in particular, since Germany adopted recycling standards earlier than most other countries, the German FMCG market can be seen as a pioneer in sustainability and thus offers rich insights for research (Niedermeier et al. 2021; Porter and van der Linde 1995). In accordance with that Schmuck et al. (2018) indicated that in comparison with the USA, German consumers had a higher identification rate of false green claims by corporations. Those claims were viewed as attempts at greenwashing. Hence, sampling German consumers promises a rich consideration of environmental issues.

Our approach to address our research questions relies on three consecutive studies (see Fig. 1). We introduce our research design before revealing specific aspects of data collection, data analysis and the corresponding findings per study.

The picture presented by the brand extension literature neglects the field of green brand extensions and the possible

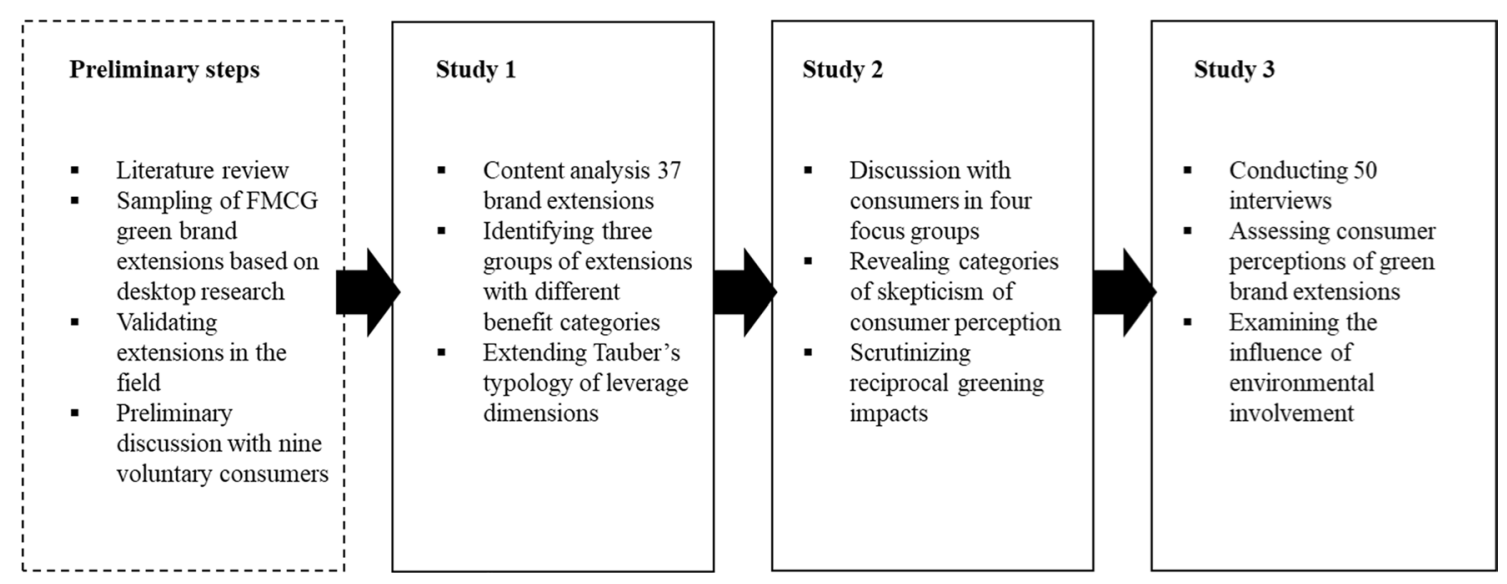

Fig. 1 Research design and main findings 
types in which they occur. Consequently, in a first step (see Fig. 1), we assessed types and characteristics of green brand extensions in the German FMCG market by applying Tauber's (1988) category system - which is, to our best knowledge, still a unique typology of levers of brand extensions. To carve out characteristics, identify types and explore new ways of leveraging brands, we conducted a deductive-inductive content analysis (Mayring 2004). We rationally applied a qualitative instead of quantitative approach to understand and illustrate the hitherto unknown phenomenon of categorizing green brand extensions. In this process, Tauber's (1988) seven types of leverage of brand extensions were transformed into researchable and valuable units.

In a second step (see Fig. 1), we added an examination of how consumers perceive and evaluate green brand extensions. Using focus group research, Study 2 sheds light on what kinds of beliefs about brand extensions consumer harbor. By sampling a well-educated group of German consumers, we were able to delve deeper into the more critical perspectives on such brand strategies. Furthermore, we wanted to understand whether consumers perceive a reciprocal greening impact, as intended by the companies, and if yes, how consumers respond to it.

In a third complementary step (see Fig. 1), we aimed for triangulation of the perspective of well-educated consumers. Hence, we widened the range of participants, aiming for consumers with different levels of environmental involvement, to scrutinize the prior findings. Accordingly, with 50 interviews, we examined the role of environmental involvement regarding the perception of green brand extensions. Furthermore, we investigated the correlation of the generated perception patterns and the environmental involvement of the interviewees. We then assessed the perception of green brand extensions in general again in order to determine possible differences between the homogeneous focus groups (with generally more skeptical perceptions) in Study 2 and a heterogeneous sample of interviewees in Study 3.

\section{Study 1: Practices of green brand extensions}

Aiming for a solid assessment of FMCG brands that deal with green brand extensions on the German market, our selection of brands was primarily guided by brand value and brand relevance. The list of the top 500 most valuable brands-as reported in the Brand Finance report (Brand Finance 2019)—complemented with 50 brands evaluated in the Prophet Brand Relevance Index (Schaar and Kroll 2019) was the starting point to separate out relevant suitable FMCG brands acting in the German market. As a validation, an in-store observation was carried out by documenting possible sustainable extensions in two large supermarkets in Koblenz, Germany. The entire procedure resulted in 37 green brand extensions in seven product categories as a data basis (see Table 2), which provided a sufficient number both to identify types and characteristics as well as to act as a basis for our consecutive discussions. Whereas many global corporations are represented (e.g., Nestlé, Unilever, Henkel, Procter \& Gamble, Danone, etc.), some green brand extensions represent midsized companies with a higher degree of autonomy (e.g., Schwartau, dm, Rügenwalder Mühle, Ritter Sport, etc.).

The saturation of the research was assumed after a first round of analysis (Bryman 2012). The subsequent analysis is based on textual material collected from the product packaging or labeling, corporate and brand websites, and social media accounts. In this process, deductive and inductive research strategies were merged to extend the previous literature and subsequently discuss our findings with consumers (Bryman 2012). By employing a deductive category concept, we were able to categorize the 37 green brand extensions based on Tauber's (1988) dimensions of leverage (see Fig. 2). Moreover, additional characteristics of green brand extensions were inductively distilled through interpretation (see Fig. 3). To do so, we looked for new patterns of levers while categorizing, refuting, or identifying existing dimensions of leverage. The data were coded without a preconceived arrangement of characteristics of green brand extensions, which follows the idea from grounded theory of seeking patterns and distilling categories (Glaser and Strauss 1967). Characteristics with a similar pattern, e.g., green brand extensions with the selling proposition of less environmental degradation, were grouped into categories (Morgan 1993). In this process, we identified a highly condensed list of three corresponding categories. The material was subsequently reviewed again from the beginning, confirming that the data could be classified into the corresponding categories. This type of test-retest method ensured reliability of the respective results (Bryman 2012). Given the explanatory approach of our research, the codes and categorization of our research represented a preliminary step, laying the groundwork for our analytical interpretation.

A first finding is that the majority of green brand extensions are line extensions (32 of 37) manifested as an additional green product alternative with organic ingredients (e.g., in the case of food and beverages, hair care and cosmetics) or less toxic components (in the case of detergents). In most cases, originators utilize the same customer franchise and try to leverage the expertise of the parent brand to establish the extension (see Fig. 2). The number of category extensions (5 of 37) was small and did not allow for the evaluation of characterizing features.

The qualitative content analysis of the 37 brand extensions revealed characteristics that exceeded Tauber's (1988) seven types of brand extension leverage. These characteristics could not be distinctly assigned to Tauber's 
Table 2 Data set of green brand extensions

\begin{tabular}{|c|c|c|c|c|}
\hline No. & Company & Parent brand and product & Green brand extension and product & Category \\
\hline 1. & Nestlé & Nescafé Coffee & Nescafé Bio Coffee & Beverages \\
\hline 2. & Nestlé & Vittel Mineral Water & Vittel Vrucht Fruit Juice & Beverages \\
\hline 3. & Nestlé & Bübchen Skin Care & Creme Bübchen Natural Moist Wipes & Toiletries \\
\hline 4. & Nestlé & Maggi Natural \& Conscious & Maggi Natural Conscious Ingredients & Food \\
\hline 5. & Nestlé & Maggi Farmer's Market & Maggie Vegetable Bouillion & Food \\
\hline 6. & Nestlé & Nesquik Cocoa Pouder & Nesquik All Natural Porridge & Food \\
\hline 7. & Nestlé & Nesquik Cocoa Pouder & Nesquik All Natural Cocoa Pouder & Food \\
\hline 8. & Nestlé & Yes Cupcakes & Yes Tasty by Nature & Food \\
\hline 9. & L'oreal Paris & L'oreal Cosmetics & L'Oreal Botanicals & Hair care and color \\
\hline 10. & Garnier & Garnier Cosmetics & Garnier Bio & Hair care and color \\
\hline 11. & Garnier & Garnier Cosmetics & Garnier Color Herbalia & Hair care and color \\
\hline 12. & Garnier & Garnier Cosmetics & Garnier True Treasures & Hair care and color \\
\hline 13. & Danone & Fruit Gnomes Yoghurt & Frucht Gnomes Bio & Food \\
\hline 14. & Danone & Fruit Gnomes Yoghurt & Frucht Gnomes Squezzies & Food \\
\hline 15. & Beiersdorf & Nivea Skin Care & Nivea Natural Balance & Toiletries \\
\hline 16. & Beiersdorf & Nivea Skin Care & Nivea Natural Moist Wipes & Toiletries \\
\hline 17. & W. K. Kellogs & Corn Flakes & No Added Sugar & Food \\
\hline 18. & W. K. Kellogs & Corn Flakes & Raw Fruits & Food \\
\hline 19. & W. K. Kellogs & Corn Flakes & Superfood & Food \\
\hline 20. & $P \& G$ & Pampers & Pampers Aqua Pure Moist Wipes & Toiletries \\
\hline 21. & $P \& G$ & Pampers & Pampers Pure Protection Nappies & Toiletries \\
\hline 22. & Unilever & Dove Antiperspirant Spray & Dove original compressed Antiperspirant Spray & Toiletries \\
\hline 23. & Unilever & Dove Deodorant Spray & Dove Go Fresh compressed Deodorant Spray & Toiletries \\
\hline 24. & $\mathrm{dm}$ & Ebelin & Ebelin Nature & Toiletries \\
\hline 25. & $\mathrm{dm}$ & Jessa & Jessa Nature Panty Liner & Toiletries \\
\hline 26. & $\mathrm{dm}$ & S-Quito & S-Quito Free Nature & Toiletries \\
\hline 27. & $\mathrm{dm}$ & Babylove & Babylove Eco Nappies & Toiletries \\
\hline 28. & $\mathrm{dm}$ & Denk mit [Think along with] & Denk mit Nature & Detergents \\
\hline 29. & $\mathrm{dm}$ & Sanft und Sicher [Soft and gentle] & Soft and Gentle Recycling & Toiletries \\
\hline 30. & Schwartau & Schwartau Extra & Schwartau Farmer's Store & Food \\
\hline 31. & Langnese & Flotte Biene [Brisk Bee] & Brisk Bee Bio Fairtrade & Food \\
\hline 32. & Henkel & Pril & Pril Pro Nature & Cleaning products \\
\hline 33. & Melitta & Filter Papers & Filter Papers Nature & Household articles \\
\hline 34. & UHU & Glue Stick & Stic Renature & Household articles \\
\hline 35. & Rügenwalder Mühle & Meat and Sausages & Rügenwalder Mühle Veggie & Food \\
\hline 36. & Kölln & Oatmeal & Oatdrink & Beverages \\
\hline 37. & Ritter Sport & Chocolate Bars & Ritter Sport Vegan & Food \\
\hline
\end{tabular}
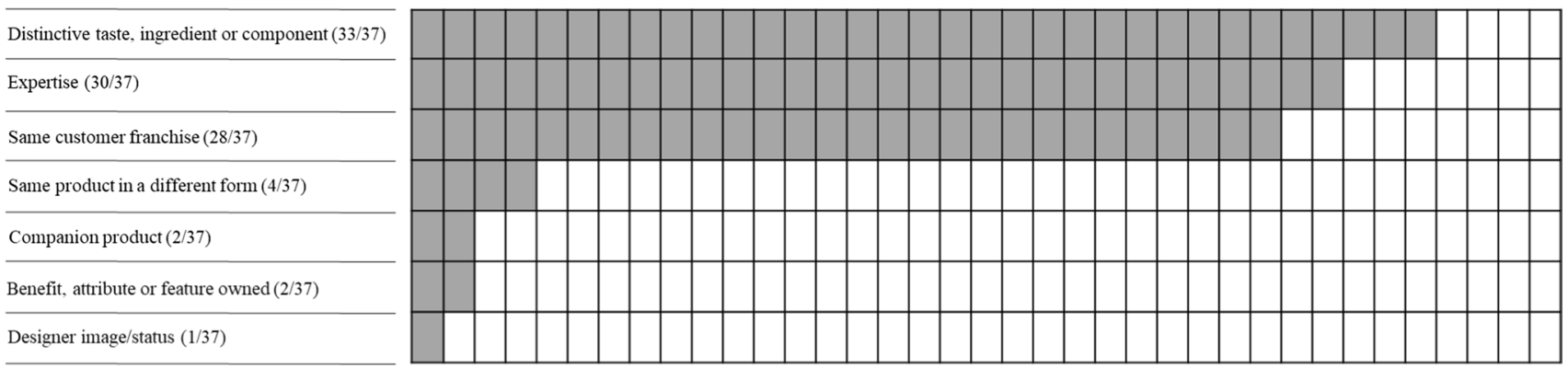

Fig. 2 Frequencies of brand extensions' dimensions (Tauber 1988) 
Benificial for the business (32/37)

Beneficial for the environment $(28 / 37)$

Beneficial for the consumer (13/37)

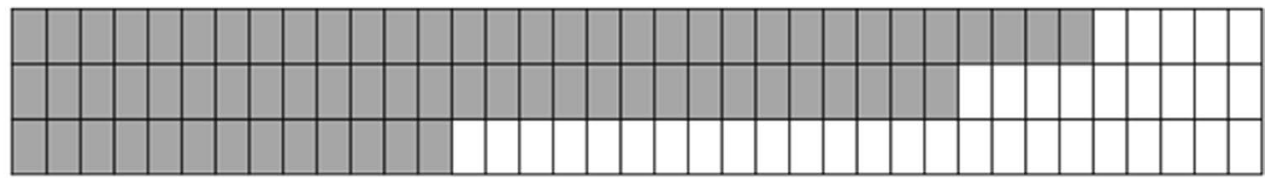

Fig. 3 Frequencies of green brand extensions' dimensions (distilled in Study 1)

(1988) categories. Hence, we inductively distilled a set of three further categories of characteristics relating to green brand extensions (see Fig. 3). Instead of a limited focus on the transferred characteristics of the parent brand in the original concept, our categorization of green brand extensions mirrors characteristics of the green brand extensions themselves. Accordingly, green brand extensions can be differentiated into subcategories that address benefits to the environment (such as less plastic waste or better recyclability) (28 of 37), benefits to the consumer (for instance, in achieving a positive health effect, fewer calories or new flavors) (13 of 37) and benefits to the business itself (by approaching additional target groups) (32 of 37). The latter category can be exemplified with the emerging consumer trend "veganism," which capitalizes on a growing demand by conscious consumers for sustainable alternatives.

In addition to this new categorization, the observed green brand extensions demonstrated the common transfer of the parent brand's quality and expertise as well as a high parent-extension fit. Ecolabels and eco certificates were also striking on packaging and in advertisements for the green brand extensions. Based on individual selected observations, we found numerous references to the production process ("bio," "vegan"), supply chain ("fair trade"), geographic origin (Germany, EU, Non-EU countries), ingredients ("organic," "vegan"), and/or recycling ("reusable") were found on the green brand extensions. We note that eco-friendly packaging, a less environmentally damaging production process and recyclability, was referred to and yet visualized less prevalently. We observed green brand extensions in various product categories where food and toiletries are overrepresented. This may be explained by the limited number of brands under examination and may not indicate that these categories are particularly appropriate for the introduction of green brand extensions. Moreover, our categorization outlines a different starting point, which is the green charisma and appeal of the green brand extension that is intended to spill over back to the parent brand. Hence, the main image transfer is expected to focus on reverse greening effects.

\section{Study 2: Facets of skepticism}

In dealing with the characteristics of green brand extensions, we decided in favor of focus group research to explore consumer responses more deeply (Bray et al. 2011). In such a setting, the free exchange between the discussants can consolidate opinions and statements on a specific topic and thus promises rich insights (Wilkinson 1998). After a preliminary pilot group discussion with nine voluntary participants, sampling strategy and moderator guideline (see Appendix) were revised and improved. Four focus groups with five to nine participants each were populated with participants of different age groups selected from the personal networks of the authors (see Table 3). However, by choosing participants with a high level of education, we theoretically sampled a group of discussants with similar consumption habits and attitudes toward green consumption, i.e., open-minded yet critical and with a more oppositional perspective. However, we were careful to avoid stereotyping or oversimplifying the selection process.

The focus groups were prepared by means of pre-formulated open-ended questions; however, their sequence was adapted to how the discussions progressed (Wilkinson 1998). Within the group discussions, we named and briefly used the green brand extensions previously identified in Study 1 as a stimulus and discussed thoughts on their characteristics. Most of the participants demonstrated brand knowledge and usage experience; yet, brand loyalty was observed by the focus group moderator to be rather low. This was particularly the case for the corporate and product brands of FMCG giants.

Next, the transcripts of the focus group discussions, which totaled more than 30 pages, were analyzed by employing qualitative content analysis (Mayring 2004). After a first analysis of the material, theoretical saturation of the data

Table 3 Demographic details of focus group participants

\begin{tabular}{llll}
\hline & No & Average & Education \\
\hline Focus group 1 & 9 & 31.4 & University \\
Focus group 2 & 6 & 23.5 & University, High school \\
Focus group 3 & 5 & 44.6 & University \\
Focus group 4 & 7 & 20.4 & High school \\
\hline
\end{tabular}


was determined (Eisenhardt and Graebner 2007; Glaser and Strauss 1967). To structure the material and identify focal points, the first author and a co-author coded independently and distilled categories and aggregated dimensions inductively, aided by qualitative methods software.

Discussants displayed a conscious consideration of corporate activities. Green brand extensions, regardless of whether as a line extension or a category extension, were described as under "general suspicion." Figure 4 summarizes the aligned distilled categories of our qualitative content analysis and illustrates a scheme of consumers' skepticism and the potential effects on the green brand extensions and the parent brand. On the one hand, facets of skepticism were based on how the extensions were presented. Corporate claims built on ecocertificates and ecolabels created doubt. This was especially the case when ecolabels were not issued by neutral institutions but by large corporations themselves. Furthermore, discussants noted a lack of authorized specific information and an overabundance of information about the sustainability of a product. Corresponding with

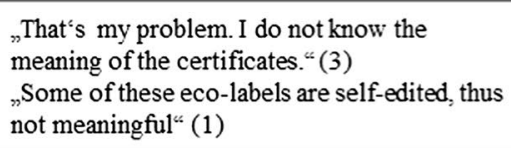

"There is too much information on the packaging. It's confusing." (2)

"Yeah, it's so messy." (4)

\section{„They do it because they have to do it to keep} their image how people would like to see it. Nowadays that is eco-friendly. "(4)

"So clearly, I think for every company the initiative for change is that they want to make more sales." (2)

"Have a look at Nestlé, they are so big that you have no clue whether they act ecologically or not." (3)

„But VioBio is not autonomous, they are dependent on Coca-Cola." (1)

"I would only trust a supplier who has always been ecological."(3)

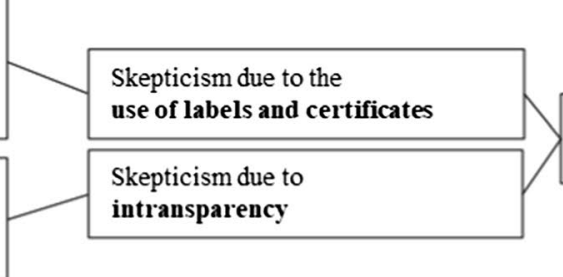

Skepticism based on product presentation

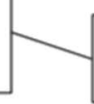

Skepticism due to image intentions/greenwashing

Skepticism due to sales intentions/market skimming

\section{product presentation}

Skepticism based on intentions

${ }_{\text {„F }}$ For me, green Coca-Cola lemonade would be greenwashing and implausible." (2)

"For me, a green extension of Maybelline is greenwashing, not credible." (4)

"VioBio as a new brand is ok, however it does not make Coca-Cola greener in any way." (4) nA veggieburger is better than a meat-burger. However, McDonald's remains one of the worst polluters." (2)

"Nevertheless those corporations are not good just based on one green product." (1)

"When I realize that they are bringing out more and more and pulling out the old products, then the company would not continue on the old track, but would already change my opinion." (3)

Fig. 4 Category building based on focus group discussions

Skepticism based on size of corporation

Skepticism based on lack of autonomy

Skepticism based on environmental reputation

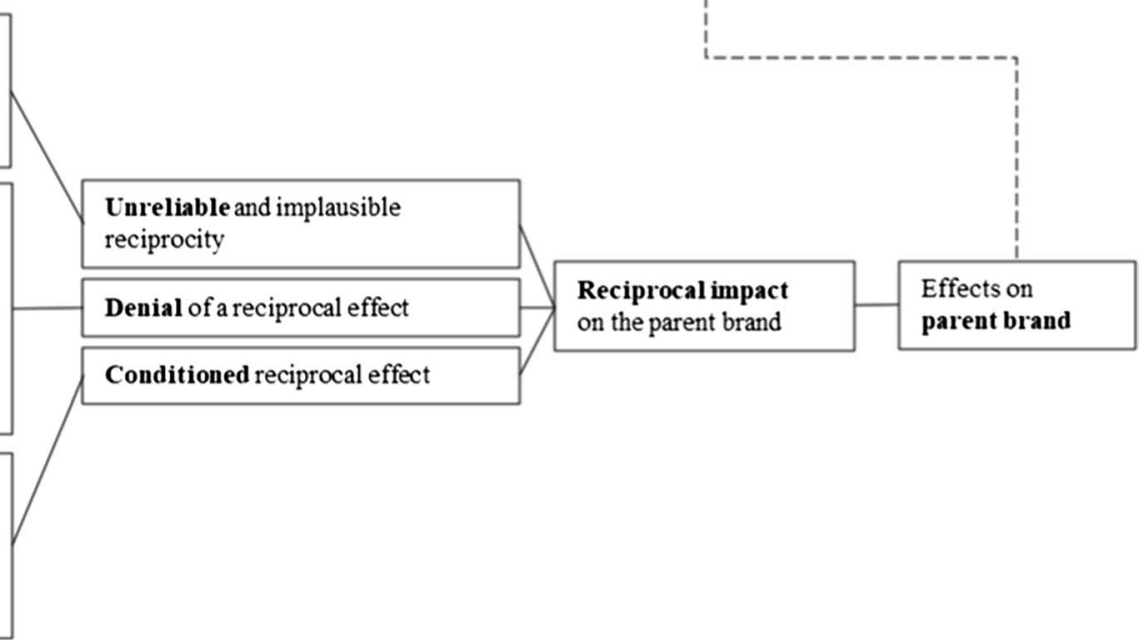

Skepticism based on sender characteristics brand extension

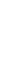


that discussants considered the intentions of the originators as image- and sales-driven. Most participants had negative preconceptions about green brand extensions and showed a fundamental distrust toward the intentions of the originators when it came to global FMCG giants such as Nestlé. Hence, whereas the green products of more autonomous midsized companies were recognized as more credible, extensions of FMCG giants were often categorized as suspicious per se by the discussants.

Additionally, we noted that there was a surge in skepticism localized to the perception of the parent brands. The share of text-blocks that we interpreted and coded as skeptical is significant in size compared to the share of text-blocks associated with positive statements. The positive statements refer to a remaining trust in brands as well as in a few stateapproved certificates. Discussants referred to parent brands' abilities and quality of production, but rarely to their environmental activities. However, discussants expressed that green brand extensions were not a consistent and appropriate strategy but that such alternatives were the "lesser evil" and a bit "better than their non-existence" (focus group 1). By focusing on the critical consumer assessments, we do not distort the picture but provide a deeper insight into the facets of skepticism of the discussion participants and illuminate the dark side of green brand extensions.

Moreover, participants discussed a hierarchy of consumption sustainability built on the dimensions of the greenness of the supplier and the greenness of the product. One discussant summed up his thoughts in this way: "The most sustainable consumption is no consumption" (focus group 2 ). The overall negative attitude toward consumption of the FMCG products of established brands is striking and can be linked to the corporates' omnipresent and targeted marketing activities as well. Discussants characterized themselves as "victims of marketing" (focus group 2), did not want to be "tricked by marketing" (focus group 2), did not want to fall into "a green pitfall" (focus group 3) or make their decisions built on "storytelling" or "marketing fairytales" (focus group 3). Moreover, what we know as reciprocal effects from the literature was not a subject of direct questioning in our focus groups. However, participants characterized green brand extensions as an illegitimate attempt by brand companies to deceptively improve their ecological image.

\section{Study 3: The influence of environmental involvement}

In a third step, we decided to deepen and triangulate the understanding we had gained up to that point. As interviews are "one of the most trustworthy and effective sources of data about consumers" (Arsel 2017, p. 939), we conducted 50 interviews offline over a period of three weeks in October and November 2020. Regarding demographic variables, i.e., gender, age, and educational level of participants, we aimed for heterogeneity (see Table 4). Consequently, we explicitly included interviewees from different generations with differing educational qualifications. Moreover, we ensured a variety of living environments with interviewees living in urban, suburban, and rural areas. Hence, our convenience sampling was intended to promise a wider mix of interviewees with different levels of environmental involvement. Following Matthes et al. (2014), we used a measurement embodying three concepts (environmental concerns, attitude toward sustainable products, sustainable consumption behavior) to assess the environmental involvement of the interviewees.

The interviewees were recruited based on the social networks of the researchers. The interviews lasted thirteen minutes on average and took place where the interviewees felt comfortable (i.e., their home, public place, or elsewhere). One interviewer conducted all semi-structured interviews along an interview guide (see Appendix), which enabled the interviewer to deepen the dialogue based on our preliminary thoughts and findings. Furthermore, we collected data about the three constructs of our variable "environmental involvement" through standardized questions. Unlike Matthes et al. (2014), we did not evaluate the effects of the individual constructs on the perceptions of our study participants who were not evaluated separately. The examination was aided by the software Qualtrics, which enabled us to stimulate the interviewees with randomized visualizations of green brand extensions.

Table 4 Details about the sample of interviewees

\begin{tabular}{llc}
\hline Variable & Category & Share in \% \\
\hline Gender & Male & 48 \\
& Female & 52 \\
Age & Diverse & 0 \\
& $\ldots-19$ & 0 \\
& $20-29$ & 24 \\
& $30-39$ & 20 \\
& $40-49$ & 18 \\
Education qualifica- & No qualification, pupils & 18 \\
& & 20 \\
& 60-59 69 & 0 \\
& Secondary school & 0 \\
& High school & 32 \\
& University & 26 \\
& Urban & 42 \\
& Suburban & 24 \\
& Rural & 20 \\
& & 56
\end{tabular}


After the interviewer transcribed the interviews verbatim, we employed an inductive qualitative content analysis following Mayring (2004) on the data set of 62 pages. In total, 402 text passages were coded while distilling categories and aggregating dimensions (see Fig. 5). Again, after two researchers coded the material, an alignment of coding schemes and categorizations was developed.

The spectrum of interviewees' responses was again from skepticism to advocacy. Interviewees expressed their attitudes toward green brand extensions, attitudes toward the parent brands and at the same time indicated whether or not the brands' environmental promises were credible. Whereas brand knowledge and product experience of the interviewees were observed repeatedly by the interviewer, brand loyalty was observed only sporadically. Interviewees responded to eco-features referring to the brand extensions, such as packaging, design, ecolabels, ingredients, origin, and recycling. Those features were categorized afterward. Again, we observed critical mental representations of huge corporations in comments such as: "It is still Nestlé, isn't it? I rate that completely poor in everything." (Interviewee 1). In addition to the size of the company, interviewees emphasized industrial production as generally eco-unfriendly: "A mass production good can never be a natural one from organic farming." (Interviewee 2). Moreover, interviewees expressed their skepticism by referring to exploitative motives of the originators of green brand extensions. In that respect, interviewees generalized from the parent brands' general habits, e.g., "industrialism," and "capitalism," to their evaluation of green brand extensions.

On the other side, interviewees expressed their acceptance based on features of the brand extension, such as official ecolabels, which are authentic, appropriate, and credible, enhanced production processes or recyclable packaging. Furthermore, interviewees also indicated that their acceptance was based on knowledge of the parent brand or brand experiences. For instance, parent brand meaning or motives of the brand were mentioned. Thus, long-term enduring experiences, e.g., about quality, were successfully leveraged to the extension.

Although our convenient sampling strategy and qualitative data analysis limit the validity of an analysis of frequencies, they can be used to support our interpretations. The interviewees expressed more support for the idea of green alternatives per se than was reported in the focus groups of Study 2. One of the green brand extensions used as a stimulus stood out, as it resulted in no negatively coded attitudes. One possible explanation is that the parent brandthe German drug store chain $\mathrm{dm}$-is a retailer brand whose corporate brand and employer brand enjoy a good reputation (Dialego 2010; Meyer and Waßmann 2011). Moreover, some of the green brand extensions in this case, e.g., recycled toilet paper, were salient in regard to their usefulness and ecological meaningfulness. Moreover, as previously observed, interview partners reported direct reciprocal effects only in exceptional cases: "In that respect Nescafé
Acceptance

\begin{tabular}{|c|}
\hline $\begin{array}{l}\text { "Schwartau is simply an } \\
\text { evergreen, known for a long time } \\
\text { and ever since well" ( } Z \text { ) }\end{array}$ \\
\hline $\begin{array}{l}\text { "The impression of L'Oreal is high } \\
\text { level, my associations with the } \\
\text { brand are high quality and a higher } \\
\text { price level." (55) }\end{array}$ \\
\hline $\begin{array}{l}\text { "For sure it is credible! They } \\
\text { highlight " } 100 \% \text { organic" and } \\
\text { whether this is not the case, they } \\
\text { are not allowed to sell it." (Q) }\end{array}$ \\
\hline $\begin{array}{l}\text { "Moreover, I think Dm is a nice } \\
\text { brand, I like the attitude of the } \\
\text { founder." (I) }\end{array}$ \\
\hline $\begin{array}{l}\text { "I find a certificate like that in } \\
\text { some way confidence-inspiring." } \\
\text { (K) }\end{array}$ \\
\hline $\begin{array}{l}\text { "The product design is appealing. I } \\
\text { like that." (6) }\end{array}$ \\
\hline $\begin{array}{l}\text { "I have had positive experiences } \\
\text { over a long time with the taste of } \\
\text { Schwartau marmalade" (K2) }\end{array}$ \\
\hline $\begin{array}{l}\text { "I like it because it is made with } \\
30 \% \text { recycled material." (N) }\end{array}$ \\
\hline $\begin{array}{l}\text { "Even though it is recycled, one } \\
\text { does not make compromises in } \\
\text { quality." (A) }\end{array}$ \\
\hline
\end{tabular}

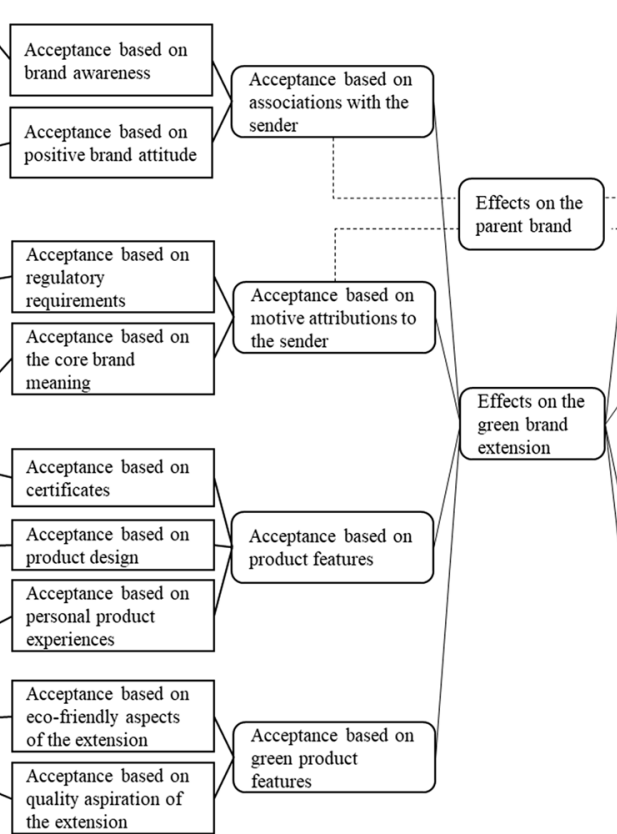

Skepticism

\begin{tabular}{|c|c|c|}
\hline & $\begin{array}{l}\text { Skepticism based on } \\
\text { size of the } \\
\text { organization }\end{array}$ & $\begin{array}{l}\text { "I no longer trust huge } \\
\text { corporations" (22) }\end{array}$ \\
\hline \multirow{3}{*}{$\begin{array}{l}\text { Skepticism based on } \\
\text { associations with the } \\
\text { sender }\end{array}$} & $\begin{array}{l}\text { Skepticism based on } \\
\text { negative brand } \\
\text { attitudes }\end{array}$ & $\begin{array}{l}\text { "There is a negative attitude } \\
\text { toward Nestlé in principle." (V) }\end{array}$ \\
\hline & $\begin{array}{l}\text { attitudes } \\
\text { Skepticism based on } \\
\text { negative CSR-brand } \\
\text { asssociations }\end{array}$ & $\begin{array}{l}\text { "It is labeled as being vegan, } \\
\text { however, they carry out lots of } \\
\text { animal experiments." (L) }\end{array}$ \\
\hline & $\begin{array}{l}\text { Skepticism based on } \\
\text { exploitative motives }\end{array}$ & $\begin{array}{l}\text { "They dress the product up as hip, } \\
\text { fresh and beautiful to charge an } \\
\text { additional Euro." (D2) }\end{array}$ \\
\hline \multirow{2}{*}{$\begin{array}{l}\text { Skepticism based on } \\
\text { motive attributions to } \\
\text { the sender }\end{array}$} & $\begin{array}{l}\text { Skepticism based on } \\
\text { sales motives }\end{array}$ & \multirow{2}{*}{$\begin{array}{l}\text { "For me, it is a fake. It is not } \\
\text { handmade marmalade since it is } \\
\text { produced in a factory." (O1) }\end{array}$} \\
\hline & \multirow{2}{*}{$\begin{array}{l}\text { Skepticism based on } \\
\text { missing brand- } \\
\text { cause fit }\end{array}$} & \\
\hline & & $\begin{array}{l}\text { "You can't label it organic while } \\
\text { taking away people's water. Go to } \\
\text { hell." (M) }\end{array}$ \\
\hline \multirow{2}{*}{$\begin{array}{l}\text { Skepticism based on } \\
\text { product features }\end{array}$} & $\begin{array}{l}\text { Skepticism based on a } \\
\text { lack of transparency }\end{array}$ & $\begin{array}{l}\text { "Do I trust in that? Simply because } \\
\text { it is a label on the packaging? I am } \\
\text { rather skeptical." (G2) }\end{array}$ \\
\hline & $\begin{array}{l}\text { Skepticism based on } \\
\text { look and feel }\end{array}$ & $\begin{array}{l}\text { "I wouldn't agree, since the look is } \\
\text { not appealing." (H) }\end{array}$ \\
\hline \multirow[t]{2}{*}{$\begin{array}{l}\text { Skepticism based on } \\
\text { green product } \\
\text { features }\end{array}$} & $\begin{array}{l}\text { Skepticism based on a } \\
\text { lack of consistency } \\
\text { (product) }\end{array}$ & $\begin{array}{l}\text { "It is simply the question whether } \\
\text { it is a good thing since it is packed } \\
\text { in plastic, and finally, not even } \\
\text { recycled plastic." (M) }\end{array}$ \\
\hline & $\begin{array}{l}\text { Skepticism based on a } \\
\text { lack of quality }\end{array}$ & $\begin{array}{l}\text { "I opt out of recycled toilet paper. } \\
\text { That scratches." (J) }\end{array}$ \\
\hline
\end{tabular}

Fig. 5 Category building based on interviews 
makes a convincing impression and steadily emphasizes its biological components" (Interviewee 3).

Our research design is mainly qualitative, and hence our sampling does not fulfill the requirements of representativity. However, by using SPSS, we were able to analyze the standardized data on the environmental involvement of the interviewees quantitatively. Relying on a tested scale, the validity and reliability of assessing environmental involvement by Matthes et al. (2014) are assumed. To maintain this, we tested for reliability with Cronbach's Alpha with very good results $(\alpha>0.8)$ (Field 2013). The interviewees can be grouped as being highly involved (six interviewees), moderately involved (34 interviewees), or lowly involved (ten interviewees) (Trommsdorff 2004). Hence, our aim to interview a heterogeneous sample was partially fulfilled. As a result, we noted that lowly involved interviewees rarely showed skepticism, i.e., the brand's exploitative motives and a low extension-parent brand fit. In contrast, highly involved interviewees demonstrated a higher level of skepticism. With reference to individual green brand extensions, a positive correlation of the product perception and the environmental involvement of respondents was proven (e.g., recycled toilet paper, $r=0.469 ; p<0.01)$. According to the regression analysis, environmental involvement has a significant influence on the perception of the green brand extension toilet paper $\left(R^{2}=0.220 ; p<0.001\right)$.

\section{Discussion}

Brand extension theory has a long history in research and practice: It is a less risky and more efficient strategy for introducing new products (Aaker and Keller 1990; Keller and Aaker 1992; Tauber 1981). Scholars have generally demonstrated that consumer evaluations of brand extensions depend on the leverage capacity of the parent brand, and the similarity and complementarity of a parent brand and an extension (Aaker and Keller 1990; Boush and Loken 1991; Park et al. 1986; Tauber 1981). When intending to introduce environmentally friendly products to the market, companies deliberately leverage their established brand names to transfer the equity of their flagship products to green brand extensions (Chatterjee 2009). Although Tauber (1988) laid the groundwork for categorizing brand extensions, no research has explored the different levers of green brand extensions (Chatterjee 2009). By distilling a structure of three categories, we offer a nuanced perspective on green brand extensions-in the FMCG market in Germany-characterized by differentiable benefits for the business, the environment, and the consumer. Correspondingly, Grimmer and Woolley (2014) classified promoting of environmental benefits as a common messaging strategy.
Whereas Olsen et al. (2014) demonstrated that "consumers' attitude toward green new products seems to have taken a positive turn" (p. 132), our research primarily illuminates a dark side of consumers' perspectives on green brand extensions of FMCG giants. Our research highlights the importance of characteristics of the originator of an extension. We interpret that the size and the environmental reputation of the parent brand's corporation is a reason for that effect. While Olsen et al. (2014) revealed that a parent firm's environmental legitimacy positively influences the reciprocal effects of a green extension on the parent brand, we observe how consumers express the transfer of negative characteristics (i.e., neglecting animal welfare or labor working conditions) from the parent to the extension. In line with Cho and Baskin (2018), we speculate that memory-based expectations of attributes embodied by parent brands have an influence on consumer perception toward green brand extensions. In contrast to prior research (Bhaduri and Copeland 2021; Liang and Fu 2021), we reveal that consumer concerns about the parent brand are more prevalent than the potential for a transfer from a green brand extension to a parent brand. Another explanation for the skepticism toward FMCG giants' extension may lie in former failed brand extensions which can be transferred to the parent brand (Jain et al. 2020).

The transfer from the parent brand to the brand extension has been a focus of research and marketing practice. In addition, Chatterjee (2009) explicitly demonstrated potential for a positive backward image transfer in the case of green brand extensions. However, our findings cannot endorse such potential for positive backward image transfers. Rather, we qualitatively see indications that intended greening backward image transfer cannot be taken for granted, particularly in the case of giant corporations that clearly intend to utilize brand extensions for a greening of their non-green parent brand image (Grimm and Malschinger 2021). We interpret from consumers' responses that any transfer requires a reference point for a fit, similarity or complementarity; this is also the case for a backward transfer, in which case most consumers could not connect the pro-environmental characteristics of the green brand extension to the non-greenness of the parent brand.

Many companies identify their green brand extensions as eco-friendly with ecolabels. Such labels are used as a heuristic in decision making and as having an important influence on consumers' evaluations of products (Alamsyah et al. 2020; Canavari and Coderoni 2019). Our research highlights that the use of ecolabeling must be considered in the context of the sender; giant corporations with a poor environmental reputation generate distrust; thus, official unimpeachable certificates are needed to mitigate these conditions. However, midsized brands may create their own labels without being accused of greenwashing. 
At the same time, our study uses the level of environmental involvement to explain the more skeptical perception of green brand extensions by interviewees and focus group discussants who are highly involved in environmental issues. This underpins the existing knowledge about the central routes of information processing by highly involved consumers (Petty and Cacioppo 1986). In addition to environmental involvement, consumer self-reports of brand knowledge, brand experience, environmental affect and brand loyalty were observed and integrated into our interpretation. We conclude that brand knowledge, brand experience or environmental affect create a mental debate on a higher construal level and are hence a breeding ground for skepticism. This interpretation builds on different indications, as Panda et al. (2019) demonstrated in their study about sustainability awareness of Indian customers. However, when purely environmental advertisements are shown to participants with higher environmental affect, those consumers showed greater purchase intention (Grimmer and Woolley 2014).

In addition, while research emphasizes the potential of brand loyalty for the evaluation of brand extensions, our study's data questions how influential brand loyalty is in the case of corporations with a poor environmental reputation (Vahdat et al. 2020). In principle, loyalty to the brand plays a role in the success of green brand extensions (Lin et al. 2017). However, most participants in our focus groups and interviews were not loyal to FMCG giant brands; hence, we could not confirm that loyalty strengthens the success of green brand extensions, except for a small number of participants who noted that their brand loyalty is built on abilities and quality.

Our research contributes to the understanding of green brand extension strategy by uncovering characteristics of green brand extensions according to their beneficiaries and benefits. Thus, we offer academic researchers a new approach to further investigate the structural categorization of environmentally friendly line extensions. In addition, we add multiple interpretations of consumer perceptions. Accordingly, we contribute to a better understanding of how consumers respond to green brand extensions.

\section{Managerial implications}

The effectiveness of green brand extensions hinges not only on how well the extension fits the parent brand, but also on brand characteristics like size of the company and consumer characteristics like environmental involvement. Generally, we conclude that brand managers should concentrate on a holistic greening approach at the core of their business, not solely on promotional activities at touch points with their customers. In other words, green marketing is a strategy rather than a tactic. Instead of superficial greening activities, companies should focus on building a strong customer relationship and brand loyalty (Liang and Fu 2021). As early as 2006, Ottman, Stafford, and Hartman coined the term green marketing myopia, demonstrating that green appeals are "not likely to attract mainstream consumers unless they offer a desirable benefit, such as cost savings or improved product performance." Our findings complement these requirements for successful green brand extensions.

Grimm and Malschinger (2021) contrast the green marketing by green "Davids," i.e., smaller brands concentrating on sustainability, with what they call green "Goliaths," i.e., established brands that aim for building a greener brand image. Our study points out the challenges such green "Goliaths" have when introducing green brand extensions and thereby intending to green the parent brand. Correspondingly, we cannot empirically substantiate the conceptually intended positive reciprocal effects of green brand extensions. In line with Grimm and Malschinger (2021) and corresponding with the learning outcome of our study, global giant brands may benefit from concentrating on consistency, authenticity, purpose, and intentions of their corporate doings rather than capitalizing on green brand extensions as a greening lever. In addition, when using ecolabeling on green brand extensions, the transparency and credibility of the labels are crucial. Furthermore, transparency about environmental information is an effective tool for brand managers to positively influence consumers' perception of green products of established brands (Bhaduri and Copeland 2021). The same applies to communicating the brand's contribution to the environment with "tangible examples of the outcome" (Iglesias et al. 2019, p. 454). Brand managers have to balance out the costs, risks and the potential of introducing green brand extensions with a challenging potential reciprocal greening impact and - as an alternative-the introduction of a new green brand. For brands with a poor environmental reputation, the latter may promise less skepticism but, at the same time, more costs and no reciprocal greening image effect.

For those brands targeting customers with a higher involvement in environmental issues, brand managers should consider that their audience processes any marketing stimulus with a higher level of skepticism. Furthermore, negative spillover effects and further downstream consequences have to be expected (Trump and Newman 2017). However, fulfilling pro-environmental requirements for greener consumption and utilizing the green consumer potential of such target groups remain an opportunity that brands can leverage with strategic attempts rather than with tactical greening focusing on image transfer. Greenwashing activities with a focus on immaterial sustainability topics can be categorized as "mismanagement of sustainability" (Maniora 2018, p. 933). 


\section{Limitations and future research}

The findings of our empirical study should also be considered in light of its limitations. First, our analysis is limited to the examination of a subset of brands in the FMCG industry in the German market. Our focus was on manufacturer brands; however, private label brands are of growing importance (Grasby et al. 2021). Moreover, our examination is limited to consumer markets. We see great potential in extending our research to B2B markets explicitly, since both customer relationships and brand loyalty are significantly important for brand management in the B2B segment. Future studies may concentrate on how brand loyalty predicts successful (green) brand extensions.

In addition, our data set of 37 green brand extensions is a snapshot and does not consider when a product was launched. Moreover, we did not explicitly consider whether participants had had individual experiences with parent brands or green brand extensions. We did not gather data about the expression of brand reputation (e.g., capability vs. social responsibility (Johnson et al. 2019)) nor did we structurally collect data about evaluations of brand's environmental reputation (i.e., positive or negative); however, discussants and interviewees emphasized the influence that parent brand reputation has on consumer perception of green brand extension and the corresponding extendibility of a brand (Johnson et al. 2019). In addition, we did not consider competitive conditions in the extension market segments and consumers' rivalry associations (Grasby et al. 2021; Liang and Fu 2021; Milberg et al. 2010). Such conditions may lead to spillover effects when brand extensions of an FMCG giant (i.e., Red Bull fruit punch) are introduced following a prior successful extension of challenger brand (i.e., Monster Energy fruit punch) (Pontes and Pontes 2021).

Adding the consumer perspective enriches our ability to interpret our findings. The same is true for our sampling strategy of focus groups and interviews, which offered rich insights into consumer perspectives. While our sampling methods aimed for a deeper understanding of consumer thoughts, it did not aim for a representation of specific populations; thus, our findings cannot be generalized. This is especially true, since our consumer samples are limited to German consumers, which does not allow for an interpretation of cross-cultural differences. Bottomley and Holden (2001) showed the relevance of cross-cultural differences in consumers' evaluations of brand extensions. We suggest a replication of our research considering cultural differences to examine whether it is necessary for companies to develop localized green brand strategies. Specifically, the differences between consumer orientation toward sustainability issues in developed versus developing and emerging markets represent a significant consideration for companies active in the international arena and thus, the development of further studies addressing that issue would be valuable.

Furthermore, consumer focus groups or interviews often "paint a rosy picture for CSR initiatives, but they suffer from social desirability bias and other validity concerns" (Ailawadi et al. 2014). Our focus group discussions were also influenced, since environmental consciousness seemed to be the desirable norm (Aagerup and Nilson 2016). We aimed for mitigation by keeping the size of the focus groups small. Nevertheless, as shown by Su et al. (2021), participants' traits, particularly life phases like parenthood, including a higher involvement in family nutrition, may have had an influence. By including environmental involvement as a predictor variable in Study 3 , we aimed at least for a mitigation of that effect. Moreover, two qualitative content analyses left room for diverging findings, since our interpretation of the textual data was subjective. However, we coded independently and aligned our findings within the research team.

\section{Conclusion}

It is particularly noticeable that more and more companies are expanding their brand name and product lines by linking them to the preservation of nature (Olsen et al. 2014). On the one hand, they are meeting demands from certain consumer groups, and, on the other hand, they are aiming to green the parent brand's image. Our paper unfolds how German FMCG brands extend existing brands with new "green" products and reveals the corresponding consumer perspective. The multiplicity of facets of skepticism confirms that companies need holistic and comprehensive strategies-not a focus on tactical greening. Discussants' skepticism regarding the greening attempts by FMCG giants incorporates an attitude toward green brand extensions as opportunistic. The unethical reputation of individual giants, be it because of unethical actions or spillover effects, limits customer trust and hurts the ethical perception of green brand extensions (Bhaduri and Copeland 2021; Chen 2010). In addition, interview data illuminate a higher skepticism for consumers with higher environmental involvement.

In sum, it is promising to incorporate the idea of green brand extensions into the brand management framework. However, green brand extension strategies should consider this study a call for restraint: A cautious approach with a gradual extension of the portfolio may be more advantageous than ignoring consumers' skepticism further on in the process of green brand extension. 


\section{Appendix 1: Focus moderator group guideline}

1. Introduction to the topic of green brand extensions by the moderator (definition, supported by product examples).

2. Consumer perception of green brand extensions:

a. Does a green sustainable product feature represent a reason to purchase?

b. Would consumers prefer sustainable alternatives to standard products?

c. Does this already happen in everyday life?

d. Which characteristics (natural ingredients, packaging design, label, etc.) do consumers perceive as most meaningful and credible?

3. Perception of the parent brand

a. Does the perception of the parent brand change after the introduction of the green extension?

b. Does the customer perception depend on the relationship that already exists with the company?

\section{Appendix 2: Interview guideline}

1. Introduction to the topic of green brand extensions and consumer perceptions by interviewers (definition, supported by product examples)

2. Stimulation with five green brand extensions

3. Dialogue about the green brand extensions

4. Dialogue about the parent brands

5. Standardized surveying of environmental involvement

6. Demographics

\section{Declarations}

Conflict of interest On behalf of all authors, the corresponding author states that there is no conflict of interest.

\section{References}

Aagerup, U., and J. Nilsson. 2016. Green consumer behavior: Being good or seeming good? Journal of Product and Brand Management 25(3): 274-284.

Aaker, D.A. 1990. Brand extensions: The good, the bad, and the ugly. MIT Sloan Management Review 31(4): 47-61.

Aaker, D.A., and K.L. Keller. 1990. Consumer evaluations of brand extensions. Journal of Marketing 54(1): 27-41.
Ailawadi, K.L., Y.J. Luan, S.A. Neslin, and G.A. Taylor. 2014. Does retailer CSR enhance behavioral loyalty: A case for benefit segmentation. International Journal of Research in Marketing 31(2): 156-167.

Alamsyah, D.P., R. Aryanto, I.D. Utama, L.S. Marita, and N.A. Othman. 2020. The antecedents model of green awareness customer. Management Science Letter 10: 2431-2436.

Alves, I.M. 2009. Green spin everywhere: How greenwashing reveals the limits of the CSR paradigm. Journal of Global Change and Governance 11(1): 1-26.

Anderson, W.T., and W.H. Cunningham. 1972. The socially conscious consumer. Journal of Marketing 36(3): 23-31.

Arsel, Z. 2017. Asking questions with reflexive focus: A tutorial on designing and conducting interviews. Journal of Consumer Research 44: 939-948.

Athavaley, A. 2009. Kicking formaldehyde out of bed. Wall Street Journal. Advance online publication 30 April. https://www.wsj. com/articles/SB10001424052748703816204574487412817324 226.

Ben \& Jerry. 2020a. Our values \& mission. Advance online publication. https://www.benjerry.com/values.

Ben \& Jerry. 2020b. Non-dairy pints. Advance online publication. https://www.benjerry.com/flavors/non-dairy.

Bhaduri, G., and L. Copeland. 2021. Going green? How skepticism and information transparency influence consumers' brand evaluations for familiar and unfamilar brands. Journal of Fashion Marketing and Management 25(1): 80-98.

Bonini, A.M., and J.M. Oppenheim. 2008. Helping 'green' products grow. The McKinsey Quartely 3(2): 1-8.

Bottomley, P.A., and S.J.S. Holden. 2001. Do we really know how consumers evaluate brand extensions? Empirical generalizations based on secondary analysis of eight studies. Journal of Marketing Research 38(4): 494-500.

Boush, D.M., and B. Loken. 1991. A process-tracing study of brand extension evaluation. Journal of Marketing Research 28(1): 16-28.

Brand Finance. 2009. Global 500 2019: The annual report on the world's most valuable and strongest brands. January 2019", advance online publication 30 April. https://brandfinance.com/ images/upload/global_500_2019_free.pdf.

Bray, J., N. Johns, and D. Kilburn. 2011. An exploratory study into the factors impeding ethical consumption. Journal of Business Ethics 98(4): 597-608.

Bryman, A. 2012. Social research methods. Oxford: Oxford University Press.

Campbell, M.C., J.J. Inman, A. Kirmani, and L.L. Price. 2020. In times of trouble: A framework for understanding consumers' responses to threats. Journal of Consumer Research 47(3): 311-326.

Canavari, M., and S. Coderoni. 2019. Green marketing strategies in the dairy sector: Consumer-stated preferences for carbon footprint labels. Strategic Change 28(4): 233-240.

Chatterjee, P. 2009. Green brand extension strategy and online communities. Journal of Systems and Information Technology 11(4): 367-384.

Chen, Y.-S. 2010. The drivers of green brand equity: Green brand image, green satisfaction, and green trust. Journal of Business Ethics 93(2): 307-319.

Chen, Y.-S., S.-T. Hung, T.-Y. Wang, A.-F. Huang, and Y.-W. Liao. 2017. The influence of excessive product packaging on green brand attachment: The mediation roles of green brand attitude and green brand image. Sustainability 9(4): 654-669.

Chen, Y.-S., A.-F. Huang, T.-Y. Wang, and Y.-R. Chen. 2020. Greenwash and green purchase behaviour: The mediation of green brand image and green brand loyalty. Total Quality Management \& Business Excellence 31(1-2): 194-209. 
Cho, Y.-N., and E. Baskin. 2018. It's a match when green meets healthy in sustainability labeling. Journal of Business Research 86: $119-129$

Chuah, S.H.-W., D. El-Manstrly, M.-L. Tseng, and T. Ramayah. 2020. Sustainability customer engagement behavior through corporate social responsibility: The roles of environmental concern and green trust. Journal of Cleaner Production 262: 121348.

Caroll, A.B. 1979. A three-dimensional conceptual model of social performance. Academy of Management Review 4(4): 497-505.

Dialego. 2010. Drugstores-A survey of Dialego AG. Aachen: Dialego AG.

Du, S., C.B. Bhattacharya, and S. Sen. 2007. Reaping relational rewards from corporate social responsibility: The role of competitive positioning. International Journal of Research in Marketing 24(3): 224-241.

Drumwright, M.E., and P.E. Murphy. 2001. Corporate societal marketing. In Handbook of marketing and society, ed. P.N. Bloom and G.T. Gundlach, 162-183. Los Angeles: Sage Publications.

Durif, F., C. Boivin, and C. Julien. 2010. In search of a green product definition. Innovative Marketing 6(1): 25-33.

Eisenhardt, K.M., and M.E. Graebner. 2007. Theory building from cases: Opportunities and challenges. Academy of Management Journal 50(1): 25-32.

Field, A.P. 2013. Discovering statistics using IBM SPSS statistics: And sex and drugs and rock'n'roll. Los Angeles: Sage Publications.

Glaser, B.G., and A. Strauss. 1967. The discovery of grounded theory: Strategies for qualitative research. New York: Aldine Publishing.

Gordon, W. 2002. Brand green: Mainstream or forever niche? London: Green Alliance.

Grasby, A., A. Corsi, J. Dawes, and C. Driesener. 2021. How loyalty extends across product categories. Journal of Consumer Behaviour. https://doi.org/10.1002/cb.1981.

Grimm, A., and A. Malschinger. 2021. Green marketing 4.0. Wiesbaden: Springer Gabler.

Grimmer, M., and M. Woolley. 2014. Green marketing messages and consumers' purchase intentions: Promoting personal versus environmental benefits. Journal of Marketing Communications 20(4): 231-250.

Griskevicius, V., J.M. Tybur, and B. Van den Bergh. 2010. Going green to be seen: Status, reputation, and conspicuous conservation. Journal of Personality and Social Psychology 98(3): 392-404.

Groza, M.D., M.R. Pronschinske, and M. Walker. 2011. Perceived organizational motives and consumer responses to proactive and reactive CSR. Journal of Business Ethics 102(4): 639-652.

Hill, J., and H. Lee. 2015. Sustainable brand extensions of fast fashion retailers. Journal of Fashion Marketing and Management 19(2): 205-222.

Hutchinson, D., J. Singh, G. Svensson, and T. Mysen. 2013. Towards a model of conscientious corporate brands: A Canadian study. Journal of Business \& Industrial Marketing 28(8): 687-695.

Iglesias, O., S. Markovic, M. Bagherzadeh, and J.J. Singh. 2018. Cocreation: A key link between corporate social responsibility, customer trust, and customer loyalty. Journal of Business Ethics 163(1): 151-166.

Iglesias, O., S. Markovic, J.J. Singh, and V. Sierra. 2019. Do customer perceptions of corporate services brand ethicality improve brand equity? Considering the role of brand heritage, brand image, and recognition benefits. Journal of Business Ethics 154(2): 441-459.

Jain, S.P., P. Mathur, M. Isaac, H. Mao, and D. Maheswaran. 2020. Brand extension failure and parent brand penalty: The role of implicit theories. Advances in Consumer Research 48: 851-856.

Johnson, Z.S., H. Mao, S. Lefebvre, and J. Ganesh. 2019. Good guys can finish first: How brand reputation affects extension evaluations. Journal of Consumer Psychology 29(4): 565-583.

Kassarjian, H.H. 1971. Incorporating ecology into marketing strategy: The case of air pollution. Journal of Marketing 35(3): 61-65.
Keller, K.L., and D.A. Aaker. 1992. The effects of sequential introduction of brand extensions. Journal of Marketing Research 29(1): $35-50$.

Kotler, P. 2011. Reinventing marketing to manage the environmental imperative. Journal of Marketing 75(4): 132-135.

Kotler, P., and K.L. Keller. 2012. Marketing management, 14th ed. London: Pearson Education.

Kroeber-Riel, W., P. Weinberg, and A. Gröppel-Klein. 2009. Konsumentenverhalten [consumer behaviour], 9th ed. München: Vahlen.

Laufer, W.S. 2003. Social accountability and corporate greenwashing. Journal of Business Ethics 43(3): 253-261.

Lin, Y.-C., and C.-C.A. Chang. 2012. Double standard: The roles of environmental consciousness in green product usage. Journal of Marketing 76(5): 125-134.

Lin, J., A. Lobo, and C. Leckie. 2017. Green brand benefits and their influence on brand loyalty. Marketing Intelligence \& Planning 35(3): 425-440.

Lerro, M., R. Vecchio, F. Caracciolo, S. Pascucci, and L. Cembalo. 2018. Consumers' heterogeneous preferences for corporate social responsibility in the food industry. Corporate Social Responsibility and Environmental Management 25(6): 1050-1061.

Liang, B., and W. Fu. 2021. The choice of brand extension: The moderating role of brand loyalty on fit and brand familiarity. Journal of Marketing Analytics 9(1): 17-32.

Ma, S.-C., and K. Kaplanidou. 2021. How corporate social responsibility and social identities lead to corporate brand equity: An evaluation in the context of sport teams as brand extensions. Sport Marketing Quarterly 30(1): 16-29.

Majid, K.A., and C.A. Russell. 2014. Giving green a second thought: Modeling the value retention of green products in the secondary market. Journal of Business Research 68(5): 994-1002.

Maniora, J. 2018. Mismanagement of sustainability: What business strategy makes the difference? Empirical evidence for the USA Journal of Business Ethics 152(4): 931-947.

Markovic, S., O. Iglesias, J.J. Singh, and V. Sierra. 2015. How does the perceived ethicality of corporate service brands influence loyalty and positive word-of-mouth? Analyzing the roles of empathy, affective commitment, and perceived quality. Journal of Business Ethics 148(4): 721-740.

Matthes, J., A. Wonneberger, and D. Schmuck. 2014. Consumers' green involvement and the persuasive effects of emotional versus functional ads. Journal of Business Research 67(9): 1885-1893.

Mayring, P. 2004. Qualitative content analysis. A Companion to Qualitative Research 1(2): 159-176.

Meyer, M., and J. Waßmann. 2011. Strategische corporate social responsibility: Konzeptionelle Entwicklung und Implementierung in der Praxis am Beispiel dm Drogeriemarkt [strategic corporate social responsibility: Conceptual development and practical implementation of the case Dm drugstore]. Research Papers on Marketing Strategy 3(2011): 25-41.

Milberg, S.J., F. Sinn, and R.C. Goodstein. 2010. Consumer Reactions to Brand Extensions in a Competitive Context: Does fit still matter? Journal of Consumer Research 37(3): 543-553.

Miniard, P.W., C.M. Alvarez, and S.M. Mohammed. 2020. Consumer acceptance of brand extensions: Is parental fit preeminent? Journal of Business Research 118: 335-345.

Morgan, D.L. 1993. Qualitative content analysis: A guide to paths not taken. Qualitative Health Research 3(1): 112-121.

Niedermeier, A., A. Emberger-Klein, and K. Menrad. 2021. Which factors distinguish the different consumer segments of green fastmoving consumer goods in Germany? Business Strategy and the Environment 30(4): 1823-1838.

Nyilasy, G., H. Gangadharbatla, and A. Paladino. 2013. Perceived greenwashing: The interactive effects of green advertising and 
corporate environmental performance on consumer reactions. Journal of Business Ethics 125(4): 693-707.

Olsen, M.C., R.J. Slotegraaf, and S.R. Chandukala. 2014. Green claims and message frames: How green new products change brand attitude? Journal of Marketing 78(5): 119-137.

Ottman, J.A., E.R. Stafford, and C.L. Hartman. 2006. Avoiding the green marketing myopia. Ways to improve consumer appeal for environmentally preferable product. Environment 48(5): 22-36.

Panda, T.K., A. Kumar, S. Jakhar, S. Luthra, J. Garza-Reyes, I. Kazancoglu, and S.S. Nayak. 2019. Social and environmental sustainability model on consumers' altruism, green purchase intention, green brand loyalty, and evangelism. Journal of Cleaner Production 243: 1-11.

Park, C.W., B.J. Jaworski, and D.J. MacInnis. 1986. Strategic brand concept-image management. Journal of Marketing 50(4): $135-145$.

Peattie, K., and A. Crane. 2005. Green marketing: Legend, myth, farce or prophesy? Qualitative Market Research: An International Journal 8(4): 357-370.

Petty, R.E., and J.T. Cacioppo. 1986. The elaboration likelihood model. Advances in Experimental Social Psychology 19: 123-205.

Polonsky, M. J. 1994. An introduction to green marketing. Electronic Green Journal 1(2).

Polonsky, M.J., and P.J. Rosenberger III. 2001. Reevaluating green marketing: A strategic approach. Business Horizons 44(5): 21-30.

Pontes, N., and V. Pontes. 2021. Spillover effects of competitive rivalry on brand extensions. Journal of Brand Management 28: 402-412.

Porter, M.E., and C. van der Linde. 1995. Green and competitive: Ending the stalemate. Harvard Business Review 73(5): 120-134.

Rahman, I., J. Park, and C.G. Chi. 2015. Consequences of 'greenwashing': Consumers' reactions to hotels' green initiatives. International Journal of Contemporary Hospitality Management 27(6): 1054-1081.

Romani, S., S. Grappi, and R.P. Bagozzi. 2016. Corporate social responsible initiatives and their effects on consumption of green products. Journal of Business Ethics 135(2): 253-264.

Sattayawaksakul, D., J.A. Cote, and L. Tiangsoongnern. 2019. Consumer evaluations of co-branding: Analyzing the relationship of brand image consistency, brand personality similarity, brand extension authenticity, and the congruency between for-profit and non-profit parent brand. Journal of Business Administration and Language 7(1): 19-26.

Schaar, B. and A. Kroll. 2019. Prophet brand relevance index. Advance online publication, 30 April: https://www.prophet.com/relevantbr ands-2019/germany/.

Schmidt, S., S. Langner, N. Hennings, K.-P. Wiedmann, E. Karampournioti, and G. Lischka. 2017. The green brand: Explicit and implicit framing effects of ecolabelling on brand knowledge. Cognent Psychology 4(1): 1-23.

Schmuck, D., J. Matthes, and B. Naderer. 2018. Misleading consumers with green advertising? An affect-reason-involvement account of greenwashing effects in environmental advertising. Journal of Advertising 47(2): 127-145.

Sharma, N. K. and G. S. Kushwaha. 2019. Eco-labels: A tool for green marketing or just a blind mirror for consumers. Electronic Green Journal 1(42).

Su, L., A. Basu Monga, and Y. Jiang. 2021. How life-role transitions shape consumer responses to brand extensions. Journal of Marketing Research 58(3): 579-594.

Suki, N.M. 2013. Green products purchases: Structural relationships of consumers' perception of eco-label, eco-brand and environmental advertisement. Journal of Sustainability Science and Management 8(1): $1-10$.

Tauber, E.M. 1981. Brand franchise extension: New product benefits from existing brand names. Business Horizons 24(2): 36-41.

Tauber, E.M. 1988. Brand leverage: Strategy for growth in a cost-control world. Journal of Advertising Research 28(4): 26-30.

Taufique, K.M., A. Vocino, and M.J. Polonsky. 2017. The influence of eco-label knowledge on pro-environmental consumer behaviour in an emerging market. Journal of Strategic Marketing 25(7): 511-529.

Trommsdorff, V. 2004. Konsumentenverhalten [consumer behaviour]. Stuttgart: Kohlhammer.

Trump, R.K., and K.P. Newman. 2017. When do unethical brand perceptions spill over to competitors? Marketing Letters 28(2): 219-230.

Vahdat, A., H. Hafezniya, Y. Jabarzadeh, and P. Thaichon. 2020. Emotional brand attachment and attitude toward brand extension. Services Marketing Quarterly 41(3): 236-255.

Victory, K., M. Nenycz-Thiel, J. Dawes, A. Tanusondjaja, and A.M. Corsi. 2021. How common is new product failure and when does it vary? Marketing Letters 32(1): 17-32.

Waßmann, J. 2013. Corporate social responsibility und Konsumentenverhalten [corporate social responsibility and consumer behaviour]. Wiesbaden: Springer Gabler.

Wilkinson, S. 1998. Focus group methodology: A review. International Journal of Social Research Methodology 1(3): 181-203.

Publisher's Note Springer Nature remains neutral with regard to jurisdictional claims in published maps and institutional affiliations.

Andreas Hesse has been a professor of marketing at Koblenz University of Applied Sciences since 2019. His main research interests include digital commerce and consumer perceptions of various marketing trends. He has published in the Journal of Business Ethics, Corporate Reputation Review, Journal of Marketing Communications, and Journal of Marketing Management and has presented his research at various international research conferences. Before his academic career, he worked in executive marketing, sales, and customer service positions for over 15 years.

Karolin Bündgen has a master's degree in Marketing and International Business from Koblenz University of Applied Sciences. During her studies, she worked for the University's International Office. Currently, she is project coordinator of DEBEKA Innovation Center.

Saskia Claren currently aims for a master's degree in Business Administration, Major Marketing from University of Münster in addition to her Bachelor of Sciences, Marketing and International Business from Koblenz, University of Applied Sciences.

Sarah Frank currently aims for a master's degree in Business Intelligence and Smart Services from Maastrich University School of Business and Economics. In addition to that, she has a master's degree in Marketing and International Business from Koblenz University of Applied Sciences. During her studies, she was able to collect various experiences in different businesses. 